\title{
Microstructural characterization of air quenched valve seat inserts obtained with AISI D2 tool steel
}

\author{
Gomes, M. P. ${ }^{1 *}$; Santos, I. P. ${ }^{1}$; Couto, C. P. ${ }^{1}$; Betini, E. G. ${ }^{1}$; Colosio, M. A ${ }^{2}$; Rossi, J. L. ${ }^{1}$ \\ 1 Instituto de Pesquisas Energéticas e Nucleares, IPEN - CNEN, São Paulo, SP, Brazil. \\ 2 General Motors do Brasil, São Caetano do Sul, SP, Brazil. \\ *e-mail: m_gomes@outlook.com
}

\begin{abstract}
The obtention of valve seat insert (VSI) by powder metallurgy using a mixture of iron powder and tool steel is fulfilling the requirements for substitution of cobalt and lead in commercial parts, aiming cost reduction and avoid the lead toxicity. The aim of this work consisted of evaluate the influence of heat treatment on VSI obtained with AISI D2 tool steel powder. The AISI D2 tool steel powder was mixed with iron powder and additives such as manganese sulphide, zinc stearate, graphite and carbides. The heat treatment of the VSI consisted of air quenching followed by double tempering it at $500{ }^{\circ} \mathrm{C}$. The microstructural characterization was performed using scanning electron microscopy and energy dispersive spectroscopy.
\end{abstract}

Keywords: powder metallurgy, air quenching, valve seat insert, AISI D2 tool steel.

\section{Resumo}

A obtenção de insertos de assentos de válvulas (do inglês valve seat insert, VSI) pela metalurgia do pó usando a mistura de pó de ferro e aço ferramenta está atendendo as exigências de substituição do cobalto e do chumbo em componentes comerciais, almejando reduzir o custo e evitar a toxicidade do chumbo. O objetivo deste trabalho consistiu em avaliar a influência do tratamento térmico em VSI obtido com o pó de aço ferramenta AISI D2. O pó de aço ferramenta AISI D2 foi misturado com pó de ferro e aditivos como o sulfeto de manganês, estearato de zinco, grafite e carbetos. $O$ tratamento térmico dos VSI consistiu em temperá-los ao ar e duplamente revení-los a $500^{\circ} \mathrm{C}$. A caracterização microestrutural foi realizada utilizando a microscopia eletrônica de varredura e a espectroscopia por energia dispersiva.

Palavras-chave: metalurgia do pó, têmpera ao ar, inserto de assento de válvula, aço ferramenta AISI D2.

\section{Introduction}

The valve seat and valve seat insert (VSI) for intake and exhaust of gases (Fig. 1), which are partially responsible for sealing the combustion chamber, operate under stringent conditions [1].

The worst case occurs to the exhaust stroke when the temperature at the valve seat can reach 700 ${ }^{\circ} \mathrm{C}$, and at the insert seat up to $350^{\circ} \mathrm{C}$ [2].

The use of tool steels for sintered parts is a consolidated option for this application due to its good corrosion resistance, high thermal conductivity and good machining [3]. The use of powder metallurgy (P/M) components has improved the engine performance, as well as reducing its costs [4-6].

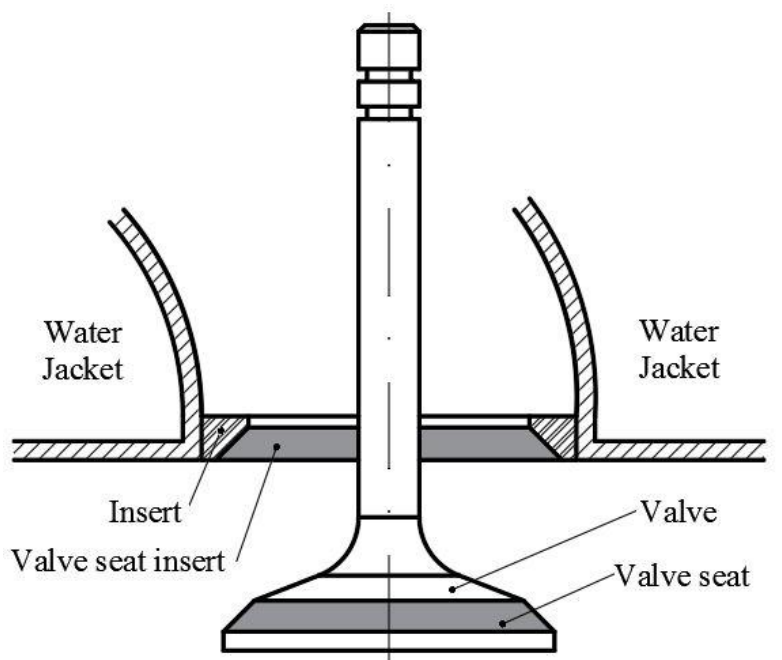

Figure 1. Schematic drawing indicating the valve and insert position in an internal combustion engine. 
The VSI studied at the present work was previously developed by Santos et al. [7-9], and their study were based on as sintered component only. The aim of this work was to heat treat and characterize microstructurally such VSI obtained with powders mixture of AISI D2 tool steel, iron, and others additives.

\section{Materials and methods}

The VSI were obtained from a mixture of powders. The powders mixtures consisted of tool steel type AISI D2 plus iron powder and others additives such as manganese sulphide, niobium carbide, graphite and zinc stearate to reduce the die-wall friction.

All the powders were mixed in an intensive mixer for $300 \mathrm{~s}$ at $1,715 \mathrm{rpm}$, except copper because it was added by metallic infiltration, i.e., two compacts were pressed from the iron powders mixtures and cooper and before the sintering process took place, these two compacts had to be put together, to mount one on top of the other.

Green compacts were obtained from the powders mixtures after compaction in a double action automated hydraulic press. The compaction was attained at a pressure of $700 \mathrm{MPa}$. The manufactured VSI from this process with dimensions of $32.5 \times 25.5 \times$ $5.9 \mathrm{~mm}^{3}$.

The compacted VSI was pre-heated up to 600 ${ }^{\circ} \mathrm{C}\left(0.275^{\circ} \mathrm{C} / \mathrm{s}\right)$ for $2,100 \mathrm{~s}$ to ensure the whole zinc stearate elimination. Then, it was sintered at $1,150{ }^{\circ} \mathrm{C}$ $\left(0.228^{\circ} \mathrm{C} / \mathrm{s}\right)$ for $2,400 \mathrm{~s}$. Finally, the VSI was cooled until room temperature with a rate of $0.335^{\circ} \mathrm{C} / \mathrm{s}$. The sintering process have been performed in a continuous commercial belt furnace under a hydrogen-based $(90 \%$ $\mathrm{H}_{2}+10 \% \mathrm{~N}_{2}$ ) atmosphere.

The sintered VSI heat treatment consisted of austenitizing it at $1,150{ }^{\circ} \mathrm{C}$ (heated at a rate of 0.480 ${ }^{\circ} \mathrm{C} / \mathrm{s}$ ) for $1,200 \mathrm{~s}$ in a laboratory muffle. In order to avoid, or at least minimize decarburization, the inserts were wrapped in a blick white sulphite drawing paper and put inside a cast iron box containing a mixture of $50 \% \mathrm{C}$ (graphite) $+50 \% \mathrm{Al}_{2} \mathrm{O}_{3}$ (aluminum oxide). This box was then put inside the muffle for heat treatment. $A$ thermocouple type $\mathrm{k}$ was attached to the samples and a data acquisition system was used to measure the cooling rate of the VSI samples. The austenitized samples were at this time, air quenched until room temperature. The quenched components were subjected to a subcritical heat treatment referred to as tempering, in a similarly way as used for the air quenching. All air quenched VSI were double tempered until room temperature, for one hour each, at $500{ }^{\circ} \mathrm{C}$.

The samples were cold mounted through a resin mixture technique, then polished using standard metallographic techniques. The samples were over etched for 50 s [10] with Nital 3\% (97\% ethyl alcohol + $3 \%$ concentrated $\mathrm{HNO}_{3}$ ) while been observed in a scanning electron microscope (SEM). The SEM in the backscattered electrons (BSE) mode was used to observe the grain structure, shape and second phases. With the support of the energy dispersive spectroscopy (EDS), it was possible to identify which phases were present at the VSI microstructure.

\section{Results and discussion}

Fig. 2 shows the elemental distribution for the Alloy 1 (AISI D2 mixture) obtained by SEM with elements identification using EDS. It was necessary to over etch the sample to discern between the tool steel matrix and the iron one, because both were added at similar amount, and reacts in a different way by the same etchant. Due to over etching, phases such as bainite ( $B$, light gray), pearlite ( $P$, medium gray), ferrite (Fe, gray) and martensite having a high carbon content (M', dark gray) seemed to be corroded. Others elements such as niobium carbide ( $\mathrm{NbC}$, white) and manganese sulfide (MnS, very dark gray) can be distinguished over the microstructure.

All the martensite ( $M$, medium dark grey) was generated from the austenite transformation from the tool steel, i.e., there is no martensite originating from the iron powder even with the addition of other elements such as graphite. In addition, it is possible to observe a thin copper ( $\mathrm{Cu}$, very light gray) distribution along the grains boundaries.

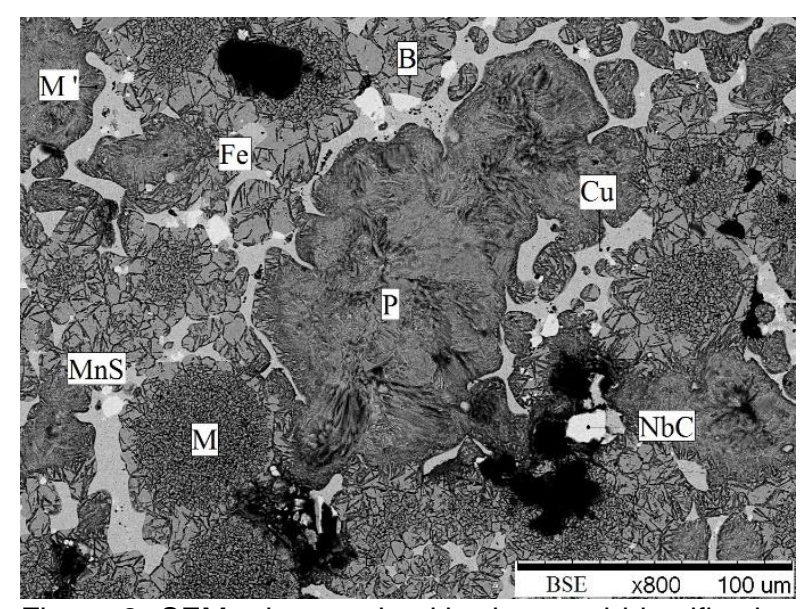

Figure 2. SEM micrograph with elemental identification using EDS of Alloy 1 (AISI D2 mixture) air quenched and double tempered at $500{ }^{\circ} \mathrm{C}$.

\section{Conclusions}

The observed overall microstructure showed to be homogeneous. 
The heat treatment proved to be efficient regarding the microstructural change.

All the AISI D2 tool steel particles in the microstructure were completely transformed into martensite, even though the air quenching imposes a soft cooling rate to the material.

Although AISI D2 tool steel is for cold work and it is going to operate under temperatures around $250{ }^{\circ} \mathrm{C}$ for intake valve seat inserts, its performance under heat treatments was evaluated due to its lower cost and it is another option of powder mixtures for the automakers manufacturing process.

\section{Acknowledgments}

The authors want to thank CAPES and CNPq for the financial support. In addition, General Motors South America, Höganäs and Group Combustol \& Metalpó for materials and equipment supply.

\section{References}

[1] JESUS FILHO, E. S.; SALGADO, L.; JESUS, S. L.; ROSSI, J. L.; COLOSIO, M. A.; SANTOS, J. C. Materials Science Forum, v. 498(9), p. 79-85, 2005.

[2] Sector Group of Powder Metallurgy. The Powder Metallurgy: Economical alternative with lower environmental impact. Brazil: Metallum Eventos Técnicos, 2009. (In Portuguese).
[3] MYERS, K. Materials World, v. 6, p. 755-756, 1999.

[4] CHANG, I.; ZHAO, Y. Advances in powder metallurgy: properties, processing and applications. Woodhead Publishing, UK, 2013.

[5] WHITTAKER, D. Metal Powder Report, v. 54(12), p. 14-21, 1999.

[6] WHITTAKER, D. The International Journal of Powder Metallurgy, v. 34(4), p. 53-62, 1998.

[7] SANTOS, I. P. Processing and characterization of sintered steels for use in valve seat inserts. Dissertation (Master in Nuclear Technology). São Paulo: IPEN-USP; 2014. (In Portuguese).

[8] GOMES, M. P.; SANTOS, I. P.; MUCSI, C. S.; COLOSIO, M. A.; ROSSI, J. L. In Proceedings of the VII Encontro Científico de Física Aplicada, Mai 11-13; Serra, ES, Brazil, p. 59-61, 2016.

[9] GOMES, M. P.; SANTOS, I. P.; COUTO, C. P.; MUCSI, C. S.; COLOSIO, M. A.; ROSSI, J. L. In Proceedings of the VIII Conferência Brasileira sobre Temas de Tratamento Térmico, May 21-24, Indaiatuba, SP, Brazil, p. 133-140, 2017.

[10] COLPAERT, H. Metallography of common metallurgical products. Editora Blucher; 2008. (In Portuguese). 